\title{
PERSEPSI MAHASISWA TERHADAP UMPAN BALIK KOREKTIF DOSEN PADA MATA KULIAH SPEAKING
}

\author{
Oleh: \\ Corry Ester Margaret Siagian ${ }^{1)}$ \\ Shabrina Harumi Pinem ${ }^{2)}$ \\ Universitas Darma Agung, Medan 1,2) \\ E-mail: \\ corryestermargaretsiagian@gmail.com $^{1)}$ \\ shabrinaharumi@gmail.com ${ }^{2}$
}

\begin{abstract}
Since many studies revealed that lecturer's corrective feedback has been givena great contribution to the development of students' English speaking skills, various studies related to it have been conducted but most of those previous studies were only focused on the implementation of corrective feedback and the types of corrective feedback engaged by the lecturers. This study was conducted to find out the students' perception toward the corrective feedback given bythe lecturers in speaking courses. By using the method of giving questionnaires to 44 students and interviews with 22 students, this study revealed that most of the students have positive perception on the lecturer's corrective feedback existence because it helped them to realize about the mistakes they made and its corrective steps that ultimately improve their speaking skills. Moreover, It lessen the students' speaking anxiety and higher their participation in speakinglessons. The type of corrective feedback thatdominantly used by the lecturers was elicitation and this was different with the students' preferred corrected feedback type, namely explicit correction. The students preferably chose explicit correctiontype becausethey directly can find what their mistakes are along with their corrective steps. The students mostlydislike metalinguistic clues because it can caused a confusing condition for them to analyze and correct the incorrect answers by themselves because of the students' lack of English speaking components' knowledge.
\end{abstract}

Keywords: Perception, Corrective Feedback, Speaking

\begin{abstract}
ABSTRAK
Sejak banyaknya penelitian yang menemukan bahwa umpan balik korektif dosen memberikan kontribusi yang tinggi terhadap perkembangan kemampuan berbicara, maka penelitian yang berhubungan dengan hal ini pun semakin berkembang namun masih terfokus kepada implementaasi umpan balik korektif dan jenis-jenis umpan balik korektif yang digunakan oleh pengajar dalam pembelajaran bahasa.Penelitian ini dilakukan untuk menemukan bagaimana persepsi mahasiswa terhadap umpan balik korektif dosen yang diberikan pada mata kuliah speaking. Dengan menggunakan metode pemberian kuesioner kepada 44 mahasiswa dan wawancara kepada 22 mahasiswa, penelitian ini menemukan bahwa sebagian besar mahasiswa memiliki persepsi yang positif terhadap keberadaan umpan balik korektif dosen karena hal tersebut menolong mereka mengetahui kesalahan yang mereka lakukan, mengetahui langkah perbaikan yang akhirnya meningkatkan kemampuan berbicara mahasiswa, memberi dampak untuk semakin berani berbicara dan meningkatkan keaktifan mahasiswa dalam pembelajaran speaking. Jenis umpan balik korektif yang paling sering digunakan oleh dosen adalah elicitation dan hal ini berbeda dengan jenis umpan balik yang disukai oleh mahasiswa, yakniexplicit correction. Mahasiswa lebih memilih explicit correction karena mahasiswa dapat mengetahui secara langsung apa yang menjadi kesalahan
\end{abstract}


mereka bersamaan dengan jawaban yang benar. Mahasiswa paling tidak menyukai jenis metalinguistic clue karena penggunaan jenis umpan balik ini mengakibatkan kebingungan bagi mahasiswa untuk menemukan kesalahan mereka sendiri karena diakibatkan oleh pengetahuan mereka mengenai komponen-komponen berbicara bahasa Inggris yang belum memadai.

\section{Kata Kunci: Persepsi, Umpan Balik Korektif dan Berbicara}

\section{PENDAHULUAN}

Kefasihan mahasiswa berbicara bahasa Inggrisyang merupakan salah satu capaian yang ingin diraih oleh dosen masih belum tercapai meskipun dosen tersebut telah memberikan umpan balik korektif terhadap mahasiswa-mahasiswanya. Di dalam proses belajar mengajar, masih saja sering terjadi kesalahan-kesalahan yang sama meskipun untuk kesalahan tersebut dosen sudah memberitahukan bahwa halhal yang mereka sampaikan kurang tepat. Jika mengacu kepada penelitian Lyster dan Ranta (1997)yang menemukan bahwa jika siswa diberikan umpan korektif yang tepat, hal itu akan menjadi sesuatu yang efektif bagi mereka untuk menyadari letak kesalahannya sehingga mampu memperbaiki kesalahan yang mereka lakukan khususnya dalam proses pencapaian akurasi penggunaan struktur gramatika dan kosakata, maka hal ini tentu membangkitkan pemikiran untuk mencari celah yang mengakibatkan mengapa hal yang seharusnya terjadi berbeda dengan kenyataan yang terjadi dalam proses pembelajaran.

Meskipun terus berkembang sesungguhnya pandangan mengenai perlu tidaknya umpan balik korektif diberikan masih beragam baik bagi peneliti. Sebagian peneliti menyatakan bahwa memberikan umpan balik akan menggangu konsentrasi mahasiswa ketika sedang fokus berbicara dan tidak terlalu berdampak signifikan terhadap peningkatan berbicara pembelajar bahasa. Namun di sisi yang berbeda, ada yang memandang bahwa pemberian umpan balik dianggap sangat penting karena dengan adanya pemberian umpan balik korektif ini, dosen dianggab telah melakukan salah satu jalan yang bertujuan untuk menolong mahasiswa menggunakan bahasa Inggris mirip seperti penutur asli. (saville-Troike, 2006.Moss dan Brookhart (2009: 44) bahkan menyampaikan bahwa umpan balik korektif tenaga pengajar dapat menjadi alat untuk menarik perhatian peserta didik selama proses pembelajaran berlangsung. Dengan adanya umpan balik ini, seperti yang ditambahkan oleh Ellis (2006:28) guru dapat menggarisbawahi kesalahan-kesalahan yang dilakukan oleh siswanya.

Penelitian mengenai umpan baik korektif semakin berkembang dari masa ke masa hingga saat ini mulai dari menganalisa jenis- jenisumpan balik korektif lisan yang sering digunakan oleh tenaga pengajar yang dianggap efektif beserta alasan penggunaanya, serta dampak umpan balik korektif lisan terhadap kemampuan berbicara siswa (Saiko,dkk: 2019). Terdapat pula topic mengenaiseberapa banyak pengajar memberikan umpan korektif tersebut kepada peserta didik (Saeb:2017). Tetapi penelitian tentang bagaiamana pendapat mahasiswa itu sendiri terhadap umpan balik dosen yang diberikan dan jenis umpan balik dosen apa yang sebaiknya diberikan oleh dosen dalam pandangan mahasiswa masih dapat dihitung dengan jari.

Respon dosen sebagai umpan balik terhadap kinerja mahasiswa adalah bagian yang biasanya bisa jadi ditunggu atau juga dihindari oleh mahasiswa.Bagaimana persepsi mahasiswa terhadap umpan balik yang diberikan dosen adalah hal yang menarik untuk dikaji karena hal ini pasti mempengaruhi motivasi mahasiswa dalam memberi diri aktif dalam praktek berbicara 
dalam pembelajaran berbicara bahasa Inggris di kelas.Mengetahui bagaimana persepsi mahasiswa tentang corrective feedbackyang diberikan dosen secara lebih mendalam tentunya dapat dijadikan menjadi sumbang fikir atau pertimbangan bagi dosen yang mengampu mata kuliah tersebut untuk memberikan strategi yang lebih disukai oleh mahasiswa sehingga dapat menjadi pertimbangan untuk menciptakan pembelajaran speaking yang lebih maksimal di kemudian hari.

\section{PERUMUSAN MASALAH}

Berdasarkan latar belakang dan masalah di atas, maka peneliti merumuskan masalah sebagai berikut:

1. Apakah persepsi mahasiswa sastra Inggris UDA terhadap umpan balik korektif dosen pada mata kuliah speaking?

2. Apakah jenis-jenis umpan korektif yang sering diberikan dosen di dalam kelas dan jenis umpan balik korektif yang menjadi preferensi mahasiswa?

3. Mengapa mahasiswa menyukai dan tidak menyukai jenis umpan balik korektif yang mereka pilih?

\section{TINJAUAN PUSTAKA}

\section{KAJIAN LITERATUR}

\section{UMPAN BALIK KOREKTIF}

Hattie dan Timperley ( 2007:81) mengatakan bahwa umpan balik korektif adalah komentar pengajar terhadap hasil yang diperlihatkan oleh peserta didik.Winnie\& Butler (1997) menambahkan bahwa umpan balik yang diberikan ini haruslah merupakan pesan yang dapat diterima oleh siswa karena hanya dengan demikianlah maka pemahaman peserta didik dapat diperbaharui. Lebih lanjut, Han (2004) menyatakan bahwa tidak adanya umpan balik korektif adalah salah satu faktor penyebab yang diduga dari fosilisasi di antara pelajar bahasa kedua.

Pada tahun 1997, Lyster dan

Ranta mengembangkan model skema observasi yang memungkinkan peneliti untuk mengamati berbagai jenis umpan balik yang diberikan guru pada kesalahan dan juga memeriksa serapan siswa.

Dua kelompok umpan balik korektif adalah:

\section{REFORMULATION}

Reformulasi berarti guru / dosen memberikan bentuk yang benar kepada para pembelajar dengan memberikan koreksi atau pengulangan secara eksplisit.

\section{PROMPTS}

Prompts dilakukan oleh dosen / guru dengan mengimbau peserta didik untuk memperbaiki diri tanpa memberikan secara langsung format/susunan/jawaban yang benar, termasuk permintaan klarifikasi, pengulangan kesalahan, petunjuk metalinguistik, dan elisitasi.

Dua kelompok umpan balik korektif ini dijabarkan lebih jelas sebagai berikut:

\section{Explicit Correction:}

Dosen langsung mengoreksi kesalahan sekaligus memberikan jawaban yang benar (misalnya mahasiswa salah mengucapkan satu kata dalam bahasa inggris, dosen langsung mengucapkan cara mengucapkan kosakata tersebut dengan benar)

\section{Recasts}

Dosen menyatakan jawaban yang benar, mahasiswa diharapkan dapat mengenali perbedaan yang diucapkan dosen dengan yang diucapkan mahasiswa.Di sini, interupsi hanya berlangsung sebentar.Dosen tidak dengan langsung menunjukkan bagian mana yang salah dari apa yang dikatakan oleh mahasiswa tersebut

\section{Clarification request:}

Dosen mengatakan ,Sorry I don't understand, atau excuse me? Dosen bisa jadi benar-benar tidak paham maksud mahasiswa tersebut atau memang sengaja berpura pura tidak paham untuk menunjukkan bahwa mahasiswa tersebut melakukan kesalahan.

\section{Repetition of error:}

Dosen mengulangi kosakata atau kalimat yang disampaikan oleh mahasiswa dengan intonasi yang meninggi seperti 
intonasi dalam bertanya, atau volume suaranya lebih ditekankan pada bagian kalimat/kosakata yang salah.

\section{Metalinguistic clue:}

Dosen bertanya secara teraterangan (dengan jelas) mengenai pola atau format dalam tata bahasa Inggris.

\section{Elicitation}

Dosen meminta mahasiswa untuk mengingat kosakata yang lebih tepat, kadang-kadang dosen mengulang kalimat mahasiswa dan akan berhenti pada bagian dimana mahasiswa tersebut melakukan kesalahan.

Selain enam jenis umpan balik korektif yang sebelumnya dijelaskan, Liskinasih(2019) menambahkan 1 (satu) jenis yakni:

\section{Reinforcement}

Reinforcement oleh Liskinasih (2019: 67) merupakan umpan balik yang mendorong mahasiswa untuk menghasilkan perbaikan berdasarkan reformulasi dosen atas ucapan yang salah yang bertujuan untuk memastikan mahasiswa mengenali bentuk yang benar dari bahasa sasaran dan menghasilkan produksi bahasa target yang dapat diterima. Dalam jenis umpan balik korektif ini, dosen meminta mahasiswa untuk mengulangi kosakata yang telah diperbaiki oleh dosen tersebut ketika mahasiswa melakukan kesalahan.

\section{METODE PELAKSANAAN JENIS DAN DESAIN PENELITIAN}

Penelitian ini menggunakan desain penelitian kualitatif deskriptif untuk mengetahui persepsi mahasiswa terhadap strategi umpan balik korektif yang diberikan oleh dosen dalam pembelajaran speakingbahasa Inggris.

\section{LOKASI DAN WAKTU PENELITIAN}

Penelitian ini dilakukan di universitas Darma Agung dalam bentuk dalam jaringan di masa pandemi covid 19. Penelitian ini dilakukan sejak Februari hingga September 2020.

\section{POPULASI DAN SAMPLING}

Penelitisecara acak meminta 42 (empat puluh dua orang) siswa untuk mengisi kuesioner dan secara purposif meminta kesediaan 22 (dua puluh dua orang) orang mahasiswa menjawab pertanyaan yang diberikan melalui wawancara.Jumlah mahasiswa yang mengisi kuisioner terdiri dari 7 (tujuh) mahasiswa semester tujuh, 10 (sepuluh) mahasiswa semester lima, 12 (dua belas) mahasiswa semester tiga dan 14 (empat belas) mahasiswa semester satuorang semester empat dan 4 (empat) orang semester enam. Keseluruhan mahasiswa ini merupakan mahasiswa Sastra Inggris di Universitas Darma Agung, Medan.

\section{METODE PENGUMPULAN DATA Angket}

Mahasiswa diminta untuk mengisi kuisioner yang berisi atas 3 bagian besar. Tiga bagian tersebut adalah bagian data diri, bagian latar belakang dan kondisi bahasa Inggris mahasiswa, dan bagian yang ketiga adalah pertanyaan-pertanyaan yang berhubungan dengan umpan balik dosen pada mata kuliah speaking. Isi kuesioner adalah pertanyaan tentang jenisjenis strategi umpan balik korektif yang digunakan dosen, cara mahasiswa memandang umpan balik korektif dosen, dan pengaruh umpan balik korektif terhadap pembelajaran speaking mahasiswa

\section{Wawancara}

Mahasiswa diminta menjawab pertanyaan untuk menggali informasi yang lebih lengkap tentang respon dan persepsi mahasiswa terhadap umpan balik yang diberikan dosen terhadap performa dan ujaran mahasiswa. Wawacara ini bersifat terstrukut namun terbuka. Narasumber dipilih secara purposive berdasarkan kriteria sebagai berikut: a) mahasiswa mendapat banyak umpan balik korektif, b) mahasiswa yang menemukan/tidak menemukan pengaruh jenis umpan balik korektif yang diberikan oleh dosen. Pelaksanaan wawancara ini diisi dengan peneliti memberikan pertanyaanpertanyaan yang mengarah kepada jawaban atas pertanyaan mengapa mahasiswa menganggap umpan balik korektif perlu atau tidak perlu,danmengapa 
mahasiswa memilih jenis-jenis umpan balik korektif seperti yang mereka pilih.

\section{METODE ANALISIS DATA}

Penelitian ini menggunakan metode analisis Miles dan Huberman. Data-data yang diperoleh berdasarkan kuesioner dan wawancara yang menjawab masalah penelitian dirangkum dalam bentuk refleksi dan disajikan dalam katakata.Data- data yang ada direfleksikan sesuai dengan pertanyaan-pertanyaan penelitian setelah data direduksi dan disajikan.Hal terakhir yang dilakukan adalah menarik kesimpulan

\section{HASIL DAN PEMBAHASAN PENELITIAN}

Persepsi mahasiswa atas perlu tidaknya umpan balik korektif dosen

Mahasiswa sangat mendukung adanya umpan balik korektif dosen karena dengan adanya pemberian umpan balik korektif dosen ini mahasiswa mengetahui kesalahan-kesalahan yang mereka lakukan. Sebagai tambahan mahasiswa juga menyatakan bahwa pemberian umpan balik dosen ini juga merupakan bukti bahwa dosen menunjukkan keperduliaannya terhadap hal yang dikerjakan mahasiswa dalam proses belajar dan mengajar speaking (berbicara bahasa Inggris).

Tabel 1. Persepsi Mahasiswa atas Perlu Tidaknya Umpan Balik Korektif dosen

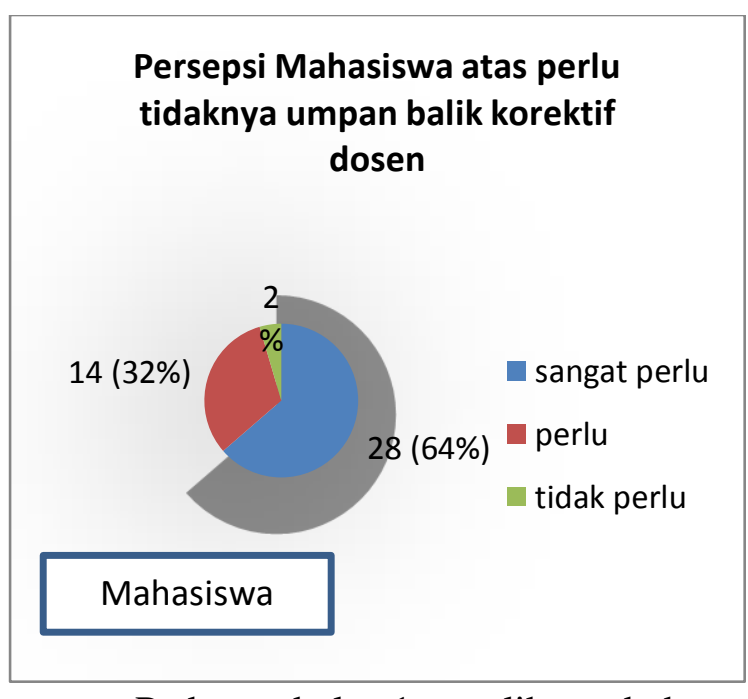

Pada tabel 1 terlihat bahwa mahasiswa menganggap bahwa umpan balik korektif sangat perlu (64\%), dan perlu (32\%).Hanya $2 \%$ dari keseluruhan mahasiswa yang menganggap umpan balik korektif yang diberikan oleh dosen tidak perlu.Sehingga secara umum dapat disimpulkan bahwa mahasiswa memberikan penilaian yang positif terhadap keberadaan umpan balik korektif dosen.

Sebagian besar mahasiswa juga menyatakan bahwa pemberian umpan balik korektif yang diberikan oleh dosen tidak memberikan gangguan terhadap performa speakingmereka.Seperti terlihat pada table 2 (dua), hanya 5 (lima) mahasiswa yang menganggap umpan balik korektif adalah gangguan ((1 (satu) orang yang sangat terganggu dan 4 (empat) orang lain terganggu ketika dosen memberikan umpan balik korektif terhadap mereka) karena umpan balik korektif tersebut diberikan pada saat kesalahan mereka terjadi, sehingga hal tersebut menggangu konsentrasi mereka ketika berbicara.
Tabel
2.
Perspektif Mahasiswaatas Gangguan Umpan Balik Korektif dosen atas Performa Speaking Mahasiswa

\section{Gangguan umpan balik korektif terhadap performa speaking}

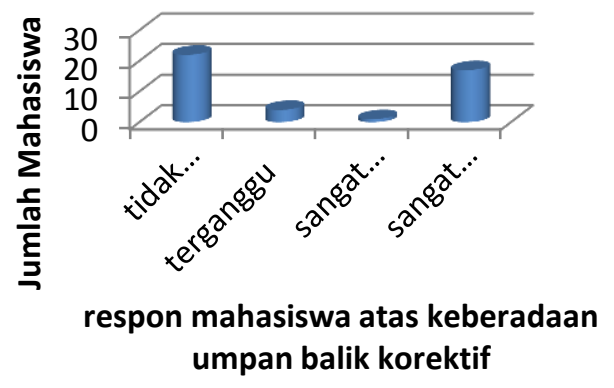

Hampir semua mahasiswa menyatakan bahwa umpan balik korektif dosen adalah respon dosen terhadap performa mereka sekaligus sebagai hal yang membuat mereka mengetahui letak kesalahan mereka sendiri maupun 
kesalahan mahasiswa yang lain. Mahasiswa menyatakan bahwa mereka sangat berharap jika dosen tetap memperbaiki kesalahan mereka dengan tetap memberikan apresiasi atas usaha mereka meskipun hasil pekerjaan mereka belum seperti yang seharusnya. Mahasiswa juga menganggap jika pemberian umpan balik dari dosen sangat bermanfaat karena dapat menjadi pijakan untuk memperbaiki kesalahan mereka.

\section{Tabel 3. Dampak Umpan Balik Dosen}

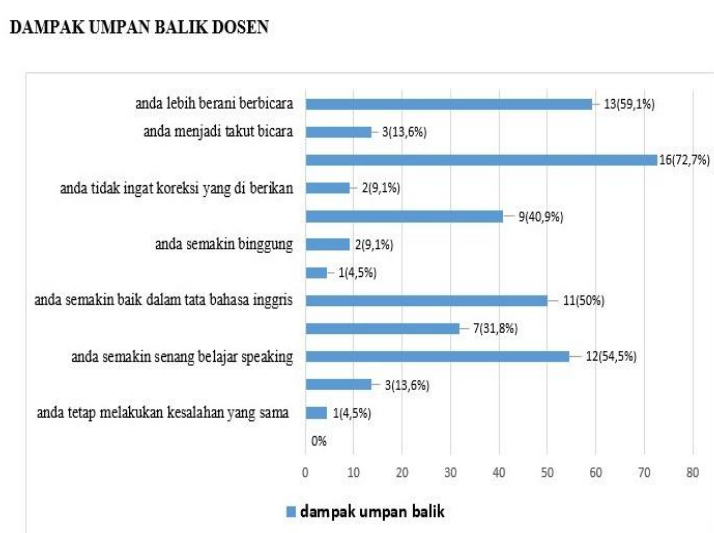

Pemberian umpan balik korektif dosen ini juga dianggapsemakin membuat mahasiswa berani berbicara $(59,1 \%)$, semakin baik dalam tata bahasa Inggris, bahkan menjadi semakin senang belajar speaking $(54,5 \%)$ meskipun ada sebagian mahasiswa yang menyatakan bahwa mereka tidak ingat perbaikan yang diberikan oleh dosen kepada mereka $(9,1 \%)$ sehingga merekapun tetap melakukan kesalahan yang sama di kemudian hari.Ditemukan pula bahawa mahasiswa merasa semakin berani berbicara karena cara penyampaian umpan balik korektif dosen dianggap baik dan suportif .

Tabel 4. Intensitas Ketakutan Berbicara Mahasiswa Akibat Umpan Balik Korektif Dosen

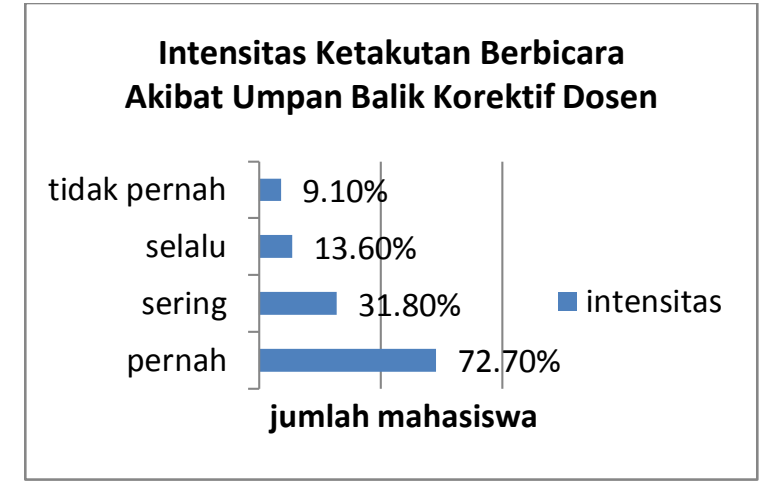

Pada awalnya, mahasiswa merasa takut jika mendapatkan umpan balik korektif dosen.72,7 \% responden menyatakan bahwa mereka pernah merasa takut untuk aktif di kelas karena terganggu dengan umpan balik yang diberikan dosen, $21 \%$ yang sering merasa takut untuk berbicara, namun hanya sebagian kecil mahasiswa ( $9,1 \%$ ) yang mengatakan tidak pernah merasa takut. Namun hal ini terjadi hanya di awal-awal pertemuan saja, ketika pertemuan demi pertemuan berlangsung, mahasiswa semakin menyadari bahwa membuat kesalahan dalam pembelajaranspeakingadalah hal yang biasa terjadi untuk menuju kelancaran dan kefasihan dalam berbicara bahasa Inggris.

Mahasiswa berpendapat bahwa pemberian umpan balik korektif yang sering disertai pujian membuat mereka semakin bersemangat ketika memberikan penampilan yang baik dan meskipun mereka melakukan kesalahan-kesalahan dosen masih memberikan apresiasi terhadap usaha atau kinerja mereka.Hal ini menjadi salah satu faktor yang mengakibatkan mahasiswa tidak takut jika dosen memberikan umpan balik korektif terhadap performa mereka.Hal yang dapat disimpulkan dalam hal ini adalah bahwa mahasiswa pernah merasa takut berbicara bahasa Inggris,tapi tidak selalu.

Tabel 5.Jenis Jenis Umpan Balik Dosen 


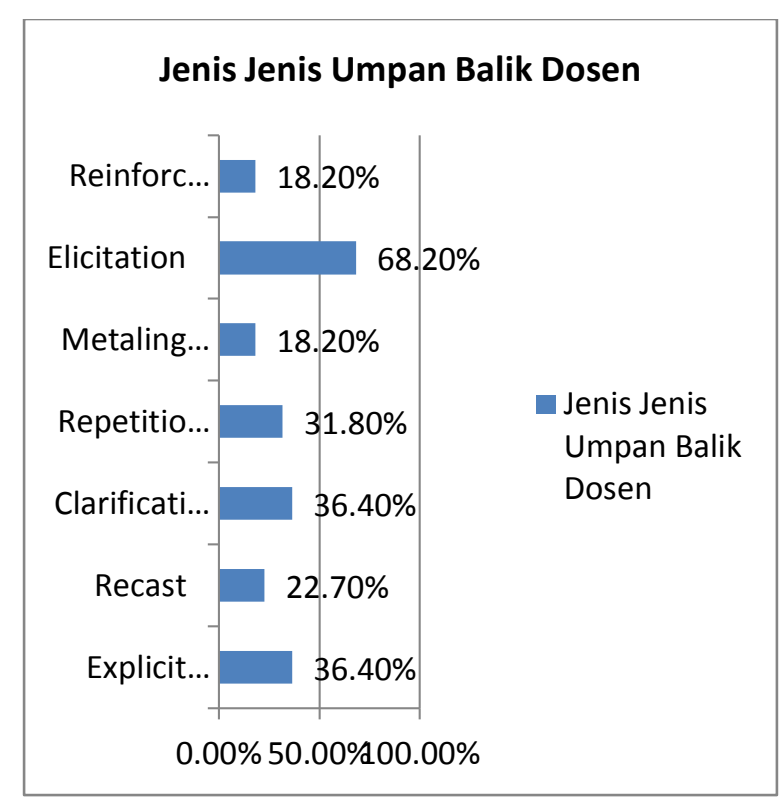

Jenis umpan balik yang digunakan dosen untuk merespon performa mahasiswa sebagai tiga jenisumpan balik korektif terbanyak adalah elicitation $(68 \%)$, clarification request $(36,4 \%)$, dan repetition of error $(31,8 \%)$, meskipun terkadang dosen juga memberi umpan balik dengan mengoreksi secara langsung seperti explicit correction (36,4\%).Pada tabel 5 ( lima) dapat dilihat pula bahwa jenis umpan balik korektif yang menurut mahasiswa cukup jarang digunakan oleh dosen adalah recast $(22,7 \%)$ dan metalingistic clue $(18,2 \%)$.

\section{Perspektif Mahasiswa Atas Jenis Jenis Umpan Balik Korektif Dosen}

Jika dibandingkan dengan preferensi mahasiswa, pada gambar di bawah kita dapat melihat bahwa ketika ditanyakan tentang mana yang lebih disukai oleh mahasiswa sebagai bentuk umpan balik yang diberikan dosen, sebagian besar mahasiswa seperti yang terlihat dalam diagram lingkaran pada gambar 1 , mahasiswa lebih memilih dikoreksi dengan diberikan jawaban yang benar secara langsung pada saaat melakukan kesalahan $(77,3 \%)$, dan sebagian kecil memilih untuk dikoreksi dengan memberikan penjelasan atau petunjuk tetapi mereka harus menemukan kesalahan itu sendiri( $22,3 \%)$.
Gambar 1. Preferensi Mahasiswa atas Jenis Umpan Balik Dosen Secara Umum PREFERENSI MAHASISWA ATAS JENIS UMPAN BALIK DOSEN

\section{Preferensi Mahasiswa atas Jenis Umpan Balik Dosen}
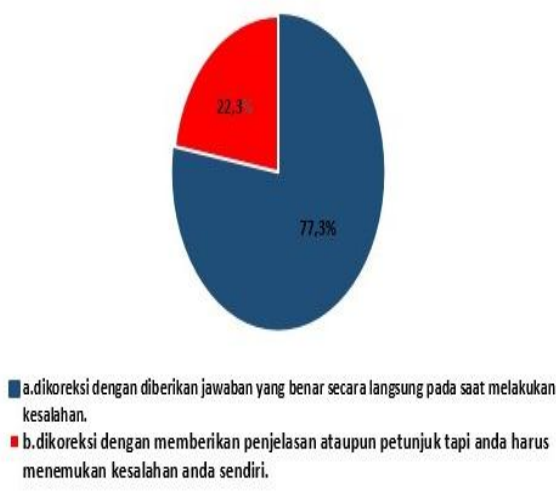

Secara lebih jelas kita dapat melihat bagaimana persentasi tingkat kesukaan mahasiswa atas jenis -jenis umpan balik korektif yang diberikan dosen pada mata kuliah speaking pada tabel 6 .

\section{Tabel 6. Preferensi Mahasiswa atas Jenis Umpan Balik Korektif dosen}

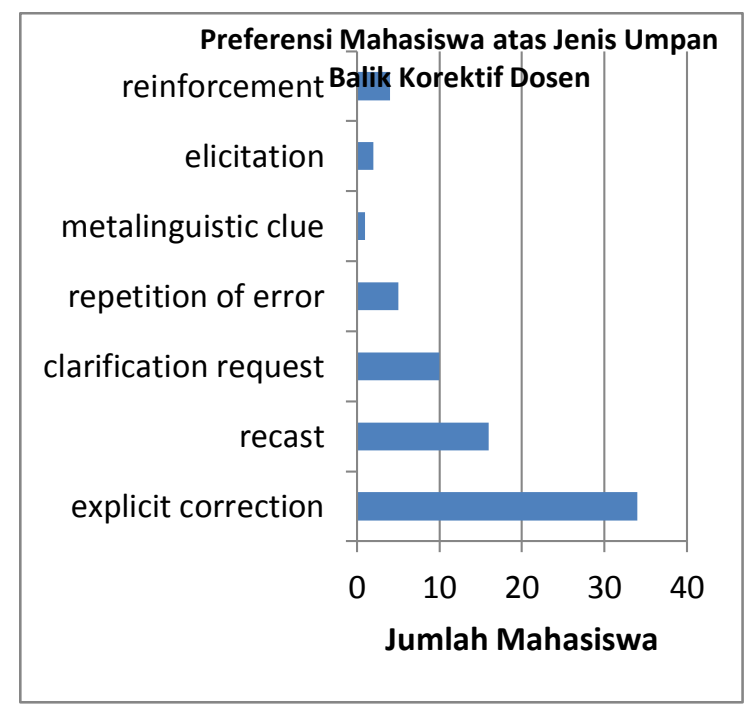

Seperti yang terlihat pada tabel 6 (enam), sebagian besar mahasiswa memilih explicit correction (34 orang), menyusul kemudian recast (16 orang), dan clarification request (10 orang).Jenis umpan balik korektif dosen yang paling tidak diminati oleh mahasiswa adalah 
metalinguistic clue ( 1 orang).Sementara itu jenis umpan balik lain yang tidak terlalu diminati oleh mahasiswa adalah elicitation ( 2 orang) reinforcement (4 orang) dan repetition of error (5 orang).

Mahasiswa lebih menyukai jenis explicit correction karena mahasiswa dapat mengetahui dengan jelas apa yang salah dan apa yang menjadi jawaban yang benar dibandingkan dengan dosen hanya menyebutkan bagian perbaikan atas hal yang salah, sementara untuk metalinguistic clue sebagian besar mahasiswa menganggap hal itu cukup membingungkan karena mereka tidak memiliki penguasaan yang memadai terhadap komponen-komponen berbicara seperti tata bahasa, kosakata, keakuratan pengucapan, koherensi yang baik sehingga mereka menganggap tipe metalinguistic clue ini lebih banyak menimbulkan kebingungan daripada memberikan pertolongan bagi mereka.

\section{PEMBAHASAN HASIL}

Penelitian ini menemukan bahwa mahasiswa menganggap bahwa umpan balik korektif dosen adalah hal yang penting dan menjadi kebutuhan bagi mereka karena dianggap dapat menjadi petunjuk dimana letak kesalahan mereka dan dapat dijadikan sebagai pondasi untuk memperbaiki diri dalam hal berbicara bahasa Inggris yang berguna di kemudian hari.Pada penelitian ini mahasiswa memberikan respon positif terhadap keberadaan umpan balik korektif dosen karena dianggab menolong mereka menjadi lebih baik dalam berbicara bahasa Inggris. Umpan balik korektif dosen ini juga membuat mahasiswa lebih ingin aktif berperan dalam pembelajaran speaking, mahasiswa sebagian besar tidak terganggu apabila dosennya memberikan umpan balik korektif.Hal ini senada dengan pendapat Saville-Troike (2006) yang menyatakan betapa pentingnya umpan balik diberikan karena dapat dijadikan sebagai salah satu cara untuk membantu peserta didik agar dapat mencapai hasil seperti penutur asli. Mahasiswa juga menambahkan jika pemberian umpan balik korektif dosen ini juga dianggap sebagai bukti bahwa dosen memperhatikan dan menghargai kinerja dan peran aktif mereka.Senada dengan hal ini, Muyashoha (2019) juga menemukan sebagian besar pelajar memiliki perspektif yang positif terhadapap umpan balik korektif dosen yang mengajak mahaiswa untuk melakukan perbaikan secara mandiri dan dengan melakukan perbaikan secara mandiri pelajar dapat pembelajaran yang berarti. Pada penelitian ini juga ditemukan bahwa penggunaan umpan balik korektif efektif dalam meningkatkan kemampuan berbicara pelajar.

Peneliti menemukan bahwa menurut mahasiswa, dosen pengampu mata kuliah speakingpaling sering menggunakan elicitation. Pilihan dosen yang ditemukan pada hasil penelitian ini berbeda dengan pilihan-pilihan yang dilakukan dosen pada penlitian-penelitian sebelumnya di tempat dan konteks yang berbeda.Mifka-Profozic menemukan pengajarumumnya menggunakan recast (Mifka-Profozic : 2012) karena jenis umpan balik korektif ini lebih efektif dalam meningkatkan kemampuan pelajar dalam kemampuan gramatikalnya. Hal ini sejalan dengan penelitian Sanz,C and Morgan-Short(2004).Lyster dan Ranta (1997), yang menyatakan bahwa Recast adalah pilihan jenis umpan balik yang disukai oleh mahasiswa. Dimana Lyster dan Ranta mengatakan bahwa recast adalah ucapan ulangan dari ucapan yang disampaikan mahasiswa sehingga mereka lebih mudah untuk menerima perbaikan dari kesalahan mereka. Padahal dalam penelitian ini dosen hanya menggunakan recast sebagai urutan kedua pada jenis umpan balik korektif yang paling jarang digunakan dosen. Hasil penelitian inipun inipun memiliki kemiripan dengan hasil Ammar and Spada (2006) yang menemukan bahwa recast dapat memberikan ambiguitas kepada siswa karena tidak secara langsung 
menginformasikan letak kesalahan pelajar. Selanjutnya, dalam penelitian ini,menurut mahasiswa, dosen juga paling jarangmenggunakan metalinguistic clue dan recast.

Sementara itu mahasiswa lebih menyukai jika dosen mereka secara langsung memperbaiki kesalahan dan secara jelas menyatakan bentuk kesalahan dan bagaimana jawaban yang benar, itulah mengapa mereka lebih memilih jika dosen speaking menggunakan explicit correction daripada metalinguistic clue karena penggunaan metalinguictic clue dianggap sebagai sesuatu yang cukup membingungkan karena terkadang mereka kurang paham terhadap istilahistilah linguistik yang diutarakan dosen. Penemuan ini mirip dengan hasilpenelitian Liskinasihyang menemukan bahwa koreksi eksplisit digunakan secara dominan seperti jenis umpan balik korektif yang juga paling diminati oleh mahasiswa pada penelitian ini. Mahasiswa juga menyadari bahwa dosen sering menggunakan strategi metalinguistic clue namun karena jenis initidak langsung menyatakan kesalahan sekaligus dengan jawaban atas kesalahan yang dilakukan oleh mahasiswa tersebut mahasiswa juga kurang meminatinya. Penemuan yang mendukung hasil penelitian ini adalah penelitian yang dilakukan Ellis yang menemukan mahasiswa lebih menyukai explicit corrective feedback karena mahasiswa lebih menyukai koreksi yang tidak ambigu. Ellis (2009) juga menyarankan agar pengajar sebaiknya memberikan koreksi secara jelas karena jika tidak, jenis umpan balik korektif yang tidak memberikan perbaikan secara langsung akan membutuhkan waktu yang lebih lama prosesnya dan tidak dapat berfungsi maksimal jika mahaiswa yang dikoreksi tidak memiliki pengetahuan yang cukup akan segi linguistik bahasa Inggris. Namun hasil penelitian ini memiliki kemiripan dengan penelitian Cubukcu
(2020:499-500) dimana mahasiswa lebih memilih elicitation dan recast sebagai salah satu jenis umpan balik yang mendapatkan jumlah preferensi yang sedikit. Tetapi juga secara kontras berbeda karena hasil penelitian cubukcu (2020), mahasiswa menempatkan translation dan explicit correction sebagai jenis umpan balik korektif yang kurang diminati.

Memiliki hasil penelitian yang mirip, Fatimatul (2019) dalam penelitiannya menemukan bahwa mahasiswa juga lebih memilih jenis umpan balik korektif explicit correctiondan repetition karena mahasiswa berfikir hal tersebut akan memotivasi mereka untuk mengingat apa yang mereka pelajari tentang berbicara, sebagai landasan yang akan menolong mereka untuk mengoreksi diri sendiri,meningkatkan kepercayaan diri mereka,dan memberikan mereka kesempatan untuk menganalisa kesalahan dan bagaimana untuk memperbaiki kesalahannya. Explicit correction dipilih karenaselain menolong mereka untuk dapat mengetahui letak kesalahan dalam speaking, mereka juga mendapatkan pembelajaran tentang bagaimana memperbaikinya, tentu hal ini memudahkan mahasiswa untuk mengerti dan memotivasi diri mereka untuk meningkatkan kemampuan berbicara bahasa Inggrisnya. Selain itu, pengajar juga memberikan penjelasan terhadap kesalahan yang peserta ajar lakukan dan hal baiknya adalah, koreksi yang diberikan ini tidak mengakibatkan mahasiswa menjadi gugupbahkan sebaliknya,pengkoreksian kesalahan tersebut berguna sebagai pengingat akan kesalahan mereka. Tetapi perlu digaris bawahi, pada penelitian ini Fatimatul juga menemukan bahwa jenis repetition, menurut mahasiswa, adalah jenis umpan balik korektif pengajar yang paling efektif dalam menolong mereka (Fatimatul:2019: 263-264) 


\section{KESIMPULAN DAN SARAN KESIMPULAN}

Melalui penelitian ini hal hal yang dapat disimpulkan adalah sebagai berikut:

1. Mahasiswa meresponi positif pemberian umpan balik korektif dan menganggap hal tersebut sangat penting karena dengan adanya umpan balik korektif dosen ini mahasiswa mengetahui kesalahan yang mereka dan teman mereka lakukan yang akhirnya berguna sebagai penolong untuk memperbaiki kesalahan dan sebagai pengingat untuk tidak melakukan kesalahan yang sama kembali di kemudian hari

2. Jenis umpan balik yang disukai oleh mahasiswa berbeda dengan jenis umpan balik korektif yang paling sering digunakan oleh dosen dalam mata kuliah speaking. Mahasiswa lebih menyukai explicit correction sementara dosen lebih sering menggunakan elicitation

3. Mahasiswa paling menyukai jenis explicit correction karena mahasiswa mendapatkan secara langsung informasi tentang letak kesalahan mereka sekaligus jawaban yang benar dan/atau cara memperbaiki kesalahannya. Mahasiswa tidak menyukai metalinguistic clue karena jenis umpan balik korektif yang diberikan dosen ini lebih sering menimbulkan kebingungan bagi mahasiswa untuk menganalisa dan memperbaiki kesalahan mereka sendiri akibat pengetahuan mereka akan komponen-komponen berbicara yang belum memadai.

\subsection{SARAN}

1. Penelitian yang sejenis dapat dilakukan dengan metode pengumpulan data yang berbeda dan sumber data yang berbeda.

2. Penelitian lanjutan seperti bagaimana dampak secara langsung umpan balik korektif dosen apabila diberikan pada saat mahasiswa melakukan kesalahan ataupun diberikan dengan memiliki jeda waktu akan memberikan sumbang fikir bagi penelitian yang berhubungan dengan topik umpan balik korektif.

\section{DAFTAR PUSTAKA}

Ammar,A.,Spada,N.2006. One Size Fits All?: Recast,Prompts, and L2 Learning.Studies in Second Language Acquisition,28:543-74

Cubukcu,Feryal.,Kubra Aksak. Corrective Feedback Preferences of Primary School and University Students. 2020.V(9)

Ellis, R., S. Loewen \& R. Erlam. 2006. "Implicit and Explicit Corrective Feedback and the Acquisition of L2 Grammar." Studies in Second Language Acquisition 28 (2):339368.

Ellis,R.2009.Corrective Feedback and Teacher Development.L2 Journal, 1(1):3-8

Ellis,R.2013.Corrective Feedback in Teacher Guides and SLA. Iranian Journal of Language Teaching Research.1(3):1-18

Fatimatul,Anita.,Slamet

Setiawan.2019.Oral Corrective Feedback in Speaking Class: Its Frequency, Students' Perceptions, and Preference. Exposure Journal. Volume 8 (2) page 257-269.

Han,Z.H.(2004).Fossilizationin adult second language acquisition.Clevedon: Cronwell Press Press,Ltd.

Hattie, J. \& H. Timperley. 2007. "The Power of Feedback." Review of Educational Research. 77 (1):81112.

Kasenda,Saiko,dkk.2019.Kesalahan Siswa dan Umpan Balik Korektif Guru pada Pengajaran Keterampilan Berbicara Bahasa Inggris di SDN Wonorejo 274 Surabaya.Mozaik Humaniora Vol.19(1):109-123

Liskinasih, Ayu.2016.Corrective Feedback in CLT-Adopted Classrooms' Interactions.Indonesian Journal of 
Applied Linguistics, Vol.6 No.1, July 2016,pp.60-69

Lyster, R. \& L. Ranta. 1997. "Corrective Feedback and Learner Uptake." Studies in Second Language Acquisition 19:37-66.

Lyster, R.\& Saito,K.(2010.b).Oral Feedback in Classroom SLA-A Meta-Analysis. Studies in Second Language Acquisition,32,265-302.

Mifka-Profozic,N.2012.Corrective

Feedback

Individual Differences and the L2 Acquisition of French Preterite and Imperfect Tenses.Unpublished Ph.D thesis.Auckland:University of AIuckland

Moss, C. M. and S. M. Brookhart. 2009. Advancing Formative Assessment in Every Classroom: A Guide for Instructional Leaders. Vancouver: Association for Supervision and Curriculum Development.

Muslem,Asnawi,et.all. Lecturers' Oral Corrective Feedback in Speaking Class: Students' Perceptions. Proceedings of the $7^{\text {th }}$ Annual International Conference (AIC) Syiah Kuala Universiity and the $6^{\text {th }}$ International Conference on Electrical Engineering and Informatics (ICELTICs),2017, October 18-2017. Banda Aceh, Indonesia.

Muyashoha, Allafia B.Aris Sugianto.2019. The Students' Perceptions Toward Oral Corrective Feedback in Speaking Class. Proceedings of the $3^{\text {rd }}$ INACELT (International Conference on English Language Teaching)

Russel,J.\&Spada,N.(2006).The

effectiveness of corrective feedback for second language acquisition: A meta-analysisof the research.In J.Norris \& L.Ortega(Eds.),Synthesizing research on language learning and teaching(pp.133-164).Amsterdam: Benjamins.
Saeb, F. 2017. Students' and Teachers' Perceptions and Preferences for Oral Corrective Feedback: Do They Match?" International Journal of Applied Linguistics and English Literature 6 (4):32-44.

Sanz,C and Morgan-Short, K. 2004. Positive evidence versus explicit rule presentation and explicit negative feedback: A Computer Assisted study. Language Learning.54 (1).Page 35-78

Saville-Troike,M (2006). Introducing second language acquisition. New York: Cambridge University Press.

Shobaha,Shohiyah.2020. The Implementati-on of Oral Corrective Feedback in EFL Classroom.Langnguage-

Edu.Vol9(1)http://riset.unisma.ac.i d/index.php/LANG/article/view/50 68

Suzuki,M.(2004). Corrective feedback and learner uptake in adult ESL classrooms. Teachers College, Columbia UniversityWorking Papers in TESOL\& Applied Linguistics, 4(2), 1-21

Winnie, P. H. \& D. L. Butler. 1994. "Student Cognition in Learning from Teaching." In International Encyclopedia of Education, edited by T. Husen \& T. Postlewaite. Oxford: Pergamon. 